\title{
Re-pedestrianising open spaces through optimising mobility in urban landscape: great importance of the small detail
}

\author{
Gintaras Stauskis, Vilnius Gediminas Technical University Lithuania
}

\begin{abstract}
Many big, average and even small towns have been dramatically car-invaded through the past twenty years in Eastern Europe. That resulted in fragmented open spaces and endangered mobility through the streets and blocks of the city. The paper addresses the issue of comfortable access to urban open space by bringing the multidimensional approach that includes aesthetical, infrastructural and social tools and applications. On the example of Joniškis town in Lithuania, the paper presents a solution toolkit for assessing the existing mobility situation, developing a re-pedestrianising action plan and programming the impact of the applied measures. The results of the multidimensional approach show that by giving priority for pedestrians against cars in urban open spaces and drive-ins cities can achieve multiple environmental and social-economic benefits. Open spaces become safer, more attractive and pleasing and more people visit them. The proposed model serves as a continuous professional development topic for landscape architects researching, teaching and designing in the private, public and non-governmental sectors.
\end{abstract}

Keywords: landscape architect, urban open space, sustainable mobility, pedestrian walks, multidimensional assessment

\section{Background}

Many cities suffer the loss of open space that they gave away for extending the driving infrastructure because of the massive car-invasion in the last two decades in Central and Eastern Europe (CEE). In Lithuania, the number of vehicles has tripled in that period, and traffic flows increased accordingly along with extended streets, parking and other infrastructure. As a result, less and less open spaces was available for citizens; in some places deprived areas appeared because new driving infrastructure obstructed walking areas and fragmented public spaces. Currently many cities in Lithuania and the other CEE countries are creating and implementing urban renewal programmes with the substantial European Union (EU) funding and are renewing streets, parks, squares and other urban spaces. Still in many cases, because of errors in design and implementation the abovementioned mobility obstacles that are curbing human access endure, and therefore the goal of having more people walking in the city core remains unachieved.

Current transport and construction technical regulation for planning and design of streets and pedestrian areas in Lithuania still poorly address the new trends in sustainable urban mobility planning [4]. One of strategic Sustainable Urban Mobility Planning (SUMP) measures is prioritising pedestrian and other non-motor mobility against car mobility that encourages more walking in public areas by keeping pedestrian walks as safe and comfortable as possible [1]. The Lithuanian regulation for design and construction of streets and local roads [5] does not regulate this particular situation when driving ways cut through the pedestrian walkways on drive- ins. The Lithuania's national regulation for the barrier-free environment [13] in its $36 \mathrm{p}$. regulates this conflict situation and says that $\mathrm{C}$ type (service) and D type (access) streets at the intersection with the pedestrian walkways should be elevated to the level of these walkways. This is a very progressive requirement; unfortunately, local authorities and landscape architects seldom implemented it in street and open space design practice (Fig. 1-3).

Pedestrian walking on smooth and continuous pavements is easy, comfortable and pleasing activity that has commuting, health promoting, socialising, explorative and other positive effects. However, walking in the open space can be unsafe in some specific points especially when the driving way cuts through the sidewalk in drive-ins into urban quarters, facility sites, internal courtyards and other spaces. If the drive in is dropped and cuts through the pedestrian walkway this is a signal of priority for the driver over the pedestrian therefore the vehicles can speed up and can miss the approaching people in small sheltered and overgrown residential or public spaces. This obstructs the walking in the internal routes of public, residential and even recreational areas. Even if the ramp pairs are provided to make the way of pedestrian down to and up from the driving way level as required by the regulation, the movement becomes uncomfortable and even dangerous, as a person should cope with the kerb-cut ramp pairs getting up and down every interval of the walkway (Fig. 4). It becomes very difficult and sometimes even impossible to cope with the interrupted walkways for many walking pedestrians: for parents with prams, for children, for the elderly 


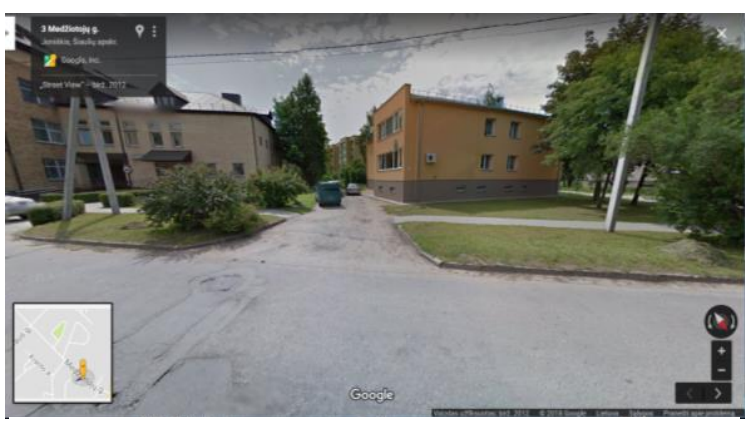

Fig. 1. Medžiotoju Street in Joniškis: the drive-in to the internal courtyard cuts through the pedestrian walk. Source: Google Street view 4.08.2018..

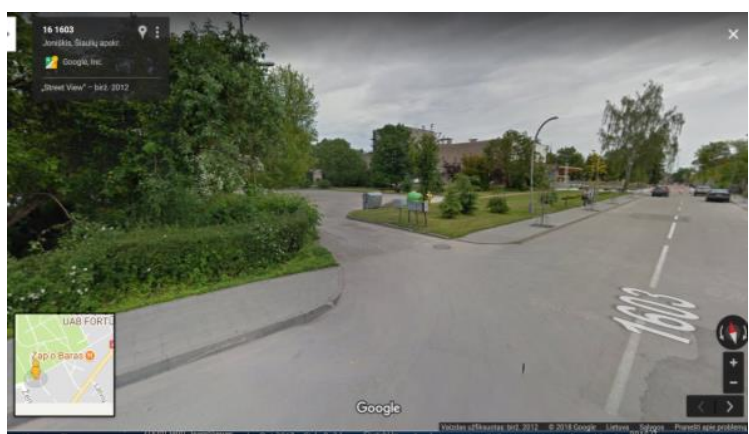

Fig. 2. Žemaičiu Street in Joniškis: the drive-in to the local park area cuts through the pedestrian walk. Source: Google Street view 4.08.2018..

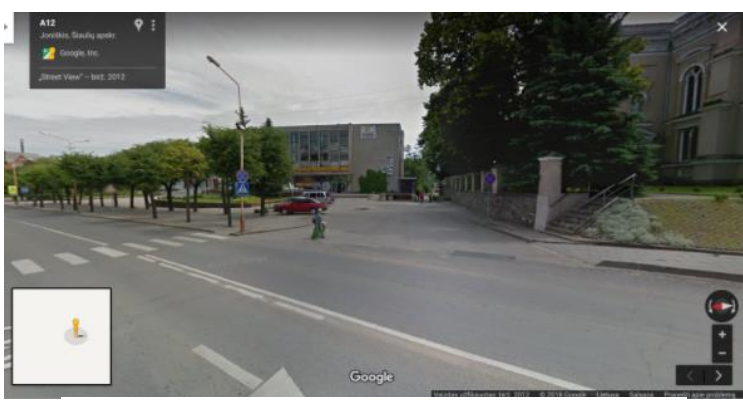

Fig. 3. Wide drive-in from Livonijos Street in Joniškis: interrupted walkway puts pedestrians in danger. Source: Google Street view 4.08.2018....

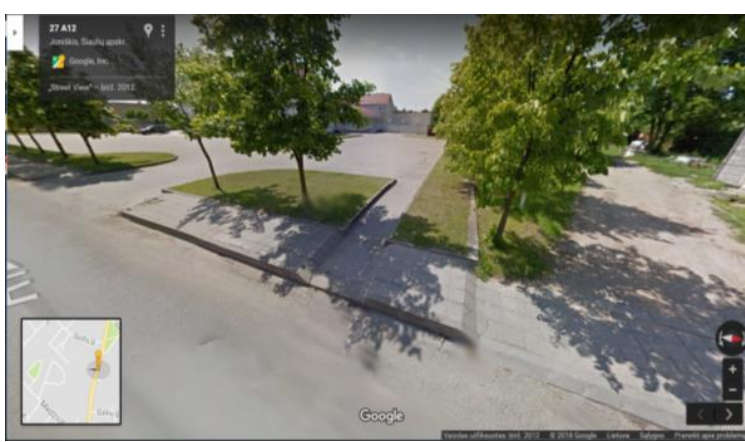

Fig. 4. Several drive-ins from Livonijos Street in Joniškis cut through the pedestrian walkway and obstruct walking. Source: Google Street view 4.08.2018......

who often have walking difficulty, for sightimpaired people, for the wheelchair users and other people of reduced mobility PRM. In different moments, rainwater and snow tends to accumulate on the dropped walkways and they become even less walkable. As an outcome, less people are using the open spaces because of obstructed, uncomfortable, dangerous and unpleasing walking conditions.

Starting with the 70 -ties of the $20^{\text {th }}$ c., many countries have installed transport planning and space design regulation as to give more priority for pedestrians by keeping walkways smooth for the users and installing the drive-through ramps for cars. Nevertheless, many open areas in Lithuanian cities still have the cut-through and interrupted walkways and suffer from the outcomes of obstructed walking and limited citizen's access to public spaces. Many streets in Joniškis that still do not have sidewalks sustain this effect (Fig. 1).

\section{Aim of the paper}

The aim of the paper is to analyse and demonstrate how the method for prioritising pedestrian mobility over car driving on pedestrian areas can improve overall safety, comfort and attractiveness of urban open spaces can encourage more people walking out in open spaces. The paper is investigating the hypothesis that the solution lies in resolving the most conflicting issues arising in the points where pedestrians collide with the vehicles on street crossing intersections and drive-ins into the urban quarters, squares and courtyards. The paper presents the results of replanned urban environment of Joniškis town in North Lithuania where these issues were resolved by the town planning and design tools and brings the comparison of "before" and "after" situation.

The paper also has several more general goals: to facilitate sustainable mobility development in urban landscapes by implementing special SUMP measures, to increase access of different user's groups to urban open spaces by making pedestrian mobility more safe, comfortable and pleasing. In addition, the paper aims to increase overall mobility safety in open spaces by reducing cardriving speed on internal urban spaces, entrances, courtyards, and squares.

\section{Methodology}

To achieve the abovementioned goals, the paper employs the set of complimentary research methods. That is background analysis; relevant literature review on mobility impact assessment; estimating state-of-the-art situation; setting the criteria groups and the set of indicators for the multicriteria impact assessment; generating the re-planning proposal for Joniškis City centre; obtaining and discussing the results; and drawing the conclusions for the used methodology. We should mention that obtaining the assessment results for all assessment indicators are based on the personal subjective Author's experience, and this is a usual perceptual experience in urban landscape. The combination of 
the used methods allows assessing the impact of the suggested measures in social, economic, environmental and artistic aspects and presenting the diversity of effects on urban landscapes, their users and the overall urban development of small and average cities in the Baltic Sea Region. In this case, Joniškis City serves as an adequate case for the proposed study.

\section{Literature review}

The way people use urban open spaces and perceive mobility opportunities in urban areas is a complex socio-psychologic phenomenon that depends on the safety, comfort conditions and satisfaction of the users [6]. Therefore, the paper analyse the reasons effecting these aspects as to pave the road to more efficient re-pedestrianising of urban centres by reducing unnecessary intersections, level changes and other obstacles for walking people.

Children are one of the most vulnerable users groups participating in mobility flow, and they tend to behave unexpectedly under unclear traffic conditions. Psychological research show that in LMIC (low- and medium-income countries) children tend to start crossing the street while noticing a gap in the traffic flow and expect drivers slowing down or swerving around them [12]. That puts them in the dangerous situations in the points of intersections with traffic flow: the more crossing they find on their way the higher is the risk of an accident.

Moving around urban open space is more difficult for persons with reduced mobility (PRM); therefore, every curb and ramp increases the needed effort and reduces the safety and comfort of travel for them. Consequently, crossing and ramps decrease the will of a person to go out and use open spaces and increases the will to stay inside at the excluded home environment [14]. For this reason, we may say that more obstacles on the travel route bring more exclusion and isolation for PRM in urban landscapes.

There is a conflict between two trends: to clear any obstacles and other objects including trees from the major city street space for increasing visibility for drivers and pedestrians, and the trend to increase traffic safety. Research show that internal urban streets and open areas that have smaller spaces and enclosed streetscapes encourage slower and more careful driving, consequently less risk with more safety and comfort for pedestrian users [7].

The Pedestrian Environment Data Scan (PEDS) methodology that can evaluate the safety and condition of the pedestrian environment emphasises that continuous and wide enough sidewalks are one of the essential elements of the pedestrian-friendly urban landscape [2]. The essential feature of an open space fit for walking is its levelled connectivity and uninterruptedness [1]. For this reason, keeping sidewalks and other pedestrian walkways continuous and uninterrupted by the driving way is an essential measure to increase the safety and comfort of walking through urban open spaces, streets, squares and parks.

Secured walking comfort helps creating or recreating the local Genius Loci of the open spaces as people are creating and using them. The research cases of small towns in Slovakia show that people when they are back to the open space help restoring the traditional ways of use and adding the new required activities to these spaces [9]. Altogether, this way leads to re-establishing the local individual character of the public or residential spaces that in its turn attracts other people to attend and use these areas more actively.

Researchers analyse and emphasise importance of the first and the last mile for the overall attractiveness of pedestrian citizens moving around the open spaces. Quality, comfort and pleasure of pedestrians using urban walkways is measured by the pedestrian attractiveness score that evaluates many technical, environmental and ergonomic criteria, and demonstrate that this score greatly depends on the quality of the built environment features along the walkway as easy and uninterrupted travel routes and public preference [10]. In the context of current research, we see multiple quality criteria that have impact on the overall quality of urban open spaces.

Walking in open spaces is an important social and physical activity that has positive impact on public health. The survey of walking citizens in Moss town in Norway has proved that walking has positive effect on health of citizens who more frequently walk from home to work and back and therefore suggests urban planning and transport infrastructure should encourage safe and pleasing walking by easily walkable continuous levelled pedestrian walkways [11]. The study suggests neighbourhoods should treat walking in open urban spaces as an important aspect of health-promoting recreation and transport activity.

Sustainable urban mobility measures are an important aspect of sustainability assessment that is included in all international (BREEAM, LEED, DGNB) and local e. g. The Lithuanian Building's Sustainability Assessment System [8]. Therefore, the measures of improving mobility safety, comfort and satisfaction are the vital instruments for sustainable development of cities as to improve their attractiveness for resident, visitors and investors.

The analysis of research experience in traffic safety, PRM empowerment, health promotion, city aesthetics, sustainability and other interconnected fields show that increasing safety, comfort and pleasure of walking areas can bring multiple positive benefits for the sustainable development of cities of different sizes, and 
reinstalling smooth, uninterrupted pedestrian walkways is one of the most important measures in this way.

\section{Re-Pedestrianising as a Landscape Planning and Design Strategy}

The paper investigates how proper urban space and landscape planning can improve safety, comfort and pleasure of walking in urban open spaces by reducing the number of street intersections (a), drive-ins from the main street to the blocks and internal facilities (b), and making all pedestrian walkways level in the points of intersection with the driving ways (c).

During spontaneous urban growth, many new street intervals were added to access the new buildings and other facilities in cities. Consequently, more drive-ins that are cutting through the pedestrian walks appeared on streets and squares (Fig. 1-4). The confusing discomfort for pedestrians arises on all street crossing and drive-ins that are cutting through the pedestrian walks. From the conceptual perspective, the problem lies in assigning the proper priority right for the pedestrians and the vehicles in mobility line's intersections. The general mobility safety rule says that the weaker party has a priority which means that pedestrians have a priority against cyclers and vehicles, and cyclists have priority against vehicles. Based on that premise, pedestrians have priority in street crossing on designated crossing lines and / or as regulated by the traffic lights and have to give the way to cars in the other driving intervals (Table 1). However, in internal quarter areas and in open urban spaces the situation is different - these areas are for the internal movement, recreation and communication of citizens; therefore the pedestrian travellers should have priority against cars and bikes, and bikes have priority against cars.

Therefore, reducing the number of street intersections by proper space planning can improve the walking conditions as a first measure. Second, reducing the number of drive-ins improves walking conditions as well as it reduces the number of pedestrian walkway interruptions. The third measure is keeping the pedestrian walks on their level as the driving way leads over it. This small detail has a great importance and potential for improving walking conditions as it signals pedestrians having priority against vehicles, for this reason vehicles slow down and let people and bicycles pass first. This rule only applies on drive-in points and not on street intersections and on crossing. Based on these measures, the paper explores the option for optimising space planning and resolving the conflicting intersection points where the drive-in way cuts through the pedestrian walkways (Fig. 5, 6).
TABLE 1

Priority in person-vehicle route intersection. Self-elaboration.

\begin{tabular}{|c|l|l|l|}
\hline No. & $\begin{array}{c}\text { Intersection } \\
\text { case }\end{array}$ & \multicolumn{2}{|c|}{ Priority } \\
\hline 1 & $\begin{array}{l}\text { Street } \\
\text { intersection }\end{array}$ & $\begin{array}{l}\text { Pedestrians } \\
\text { and bike } \\
\text { riders on } \\
\text { crossing only }\end{array}$ & $\begin{array}{l}\text { Car on the } \\
\text { rest } \\
\text { driveway }\end{array}$ \\
\hline 2 & Drive-ins & $\begin{array}{l}\text { Pedestrian } \\
\text { always } \\
\text { Bicycle } \\
\text { always }\end{array}$ & $\begin{array}{l}\text { Cars shall } \\
\text { give way }\end{array}$ \\
\hline
\end{tabular}

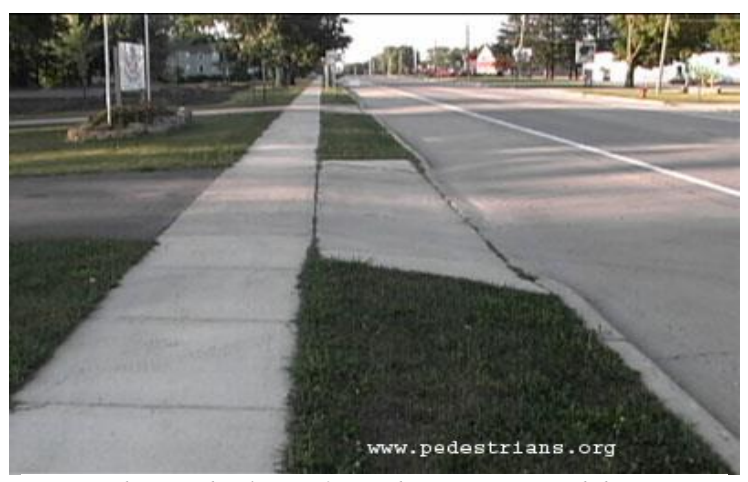

Fig. 5. The good solution for pedestrian way and driving way intersection on drive-ins to urban quarters, open areas and courtyards

Source: www.pedestrians.org [online 4.08.2018].

The central part of Joniškis town was re-planned as to improve the attractiveness of urban open spaces by optimising street network, reducing the number of street intersections and drive-ins and redesigning the remaining drive-ins as to ramp them through the levelled and elevated pedestrian walkways (drawings on Fig. 7 by Tautvilè Džiugytè, supervisor Gintaras Stauskis). We estimate the situation "before" which is a present state and "after" the design intervention by accounting the number of crossing and drive-ins and the number of redesigned drive-ins. As the next step, we estimate the possible impact of implementing the proposed changes by compiling the set of multiple social, economic, environmental and aesthetic assessment criteria. Based on literature analysis and field observation we identified the number of 16 criteria in five criteria groups: comfort of pedestrian walking, traffic safety, resource investment, impact on the environment and impact on the city aesthetics (Fig. 8). Comfort of walking is a critically important for attracting people to open spaces and depends 


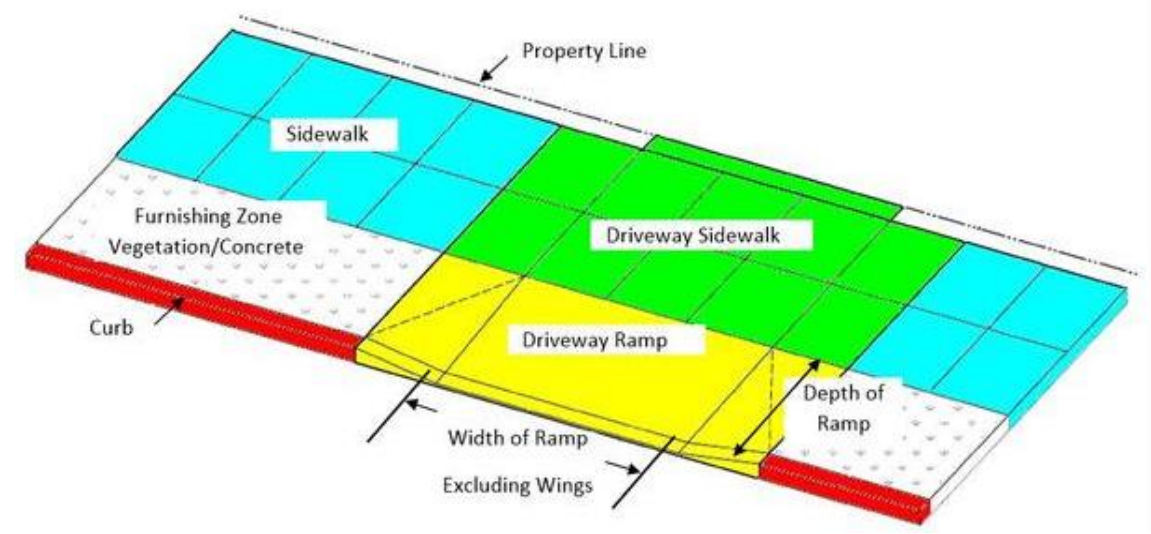

Fig. 6. The way pedestrian sidewalk should be paved on one level and the driveway is ramped across it. Used on drive-ins intersection with a pedestrian walks

Source: https://www.portlandoregon.gov/transportation/64968 [online 4.08.2018].
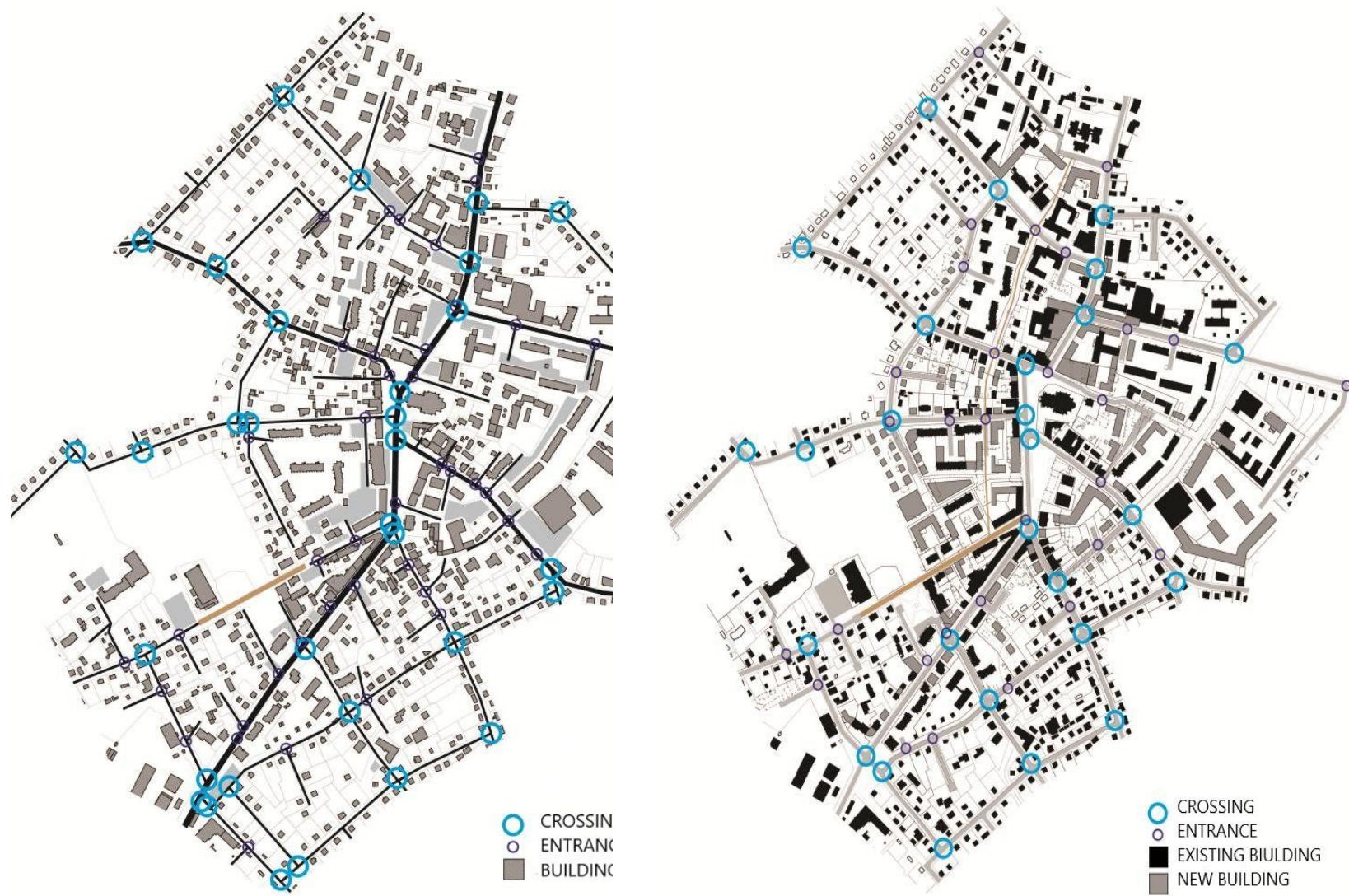

Fig. 7. The existing crossing and plot entrances (a) and the planning proposal (b) in town plan of Joniškis, Lithuania. Elaborated by T. Džiugyte...

TABLE 2

The number of crossing and plot entrances in the blocks of Lithuanian cities. Self-elaboration.

\begin{tabular}{|l|c|c|c|c|}
\hline Activity & \multicolumn{2}{|l|}{ Indicators } & $\begin{array}{l}\text { Ramped drive-ins and } \\
\text { levelled walkways }\end{array}$ \\
\cline { 2 - 5 } & Crossing number & Drive-ins number & Total: & 0 \\
\hline $\begin{array}{l}\text { Present state } \\
\text { (Figure 7a) }\end{array}$ & 35 & 41 & 76 & 30 \\
\hline $\begin{array}{l}\text { Planning proposal } \\
\text { (Figure 7b) }\end{array}$ & 26 & 30 & 56 & $\mathbf{+ 3 0}$ \\
\hline Change: & $-25,7 \%$ & $-22,0 \%$ & $\mathbf{- 2 6 , 3 \%}$ & 0 \\
\hline
\end{tabular}


how smooth are the walkways and if they have or not any obstacles, if the walking promises shortest and well visible route to the aim of travel. Traffic safety means the probability of accidents between the cars on one hand and the pedestrians and cyclists in a separate or a mixed flow, on the other hand. Economic resources are needed to install the needed mobility infrastructure and looking from the sustainability perspective that covers the construction, refurbishment and maintenance phases. Mobility make considerable impact on the environment, and therefore we should evaluate the impact of proposed measures on noise, air and visual pollution. Finally, city aesthetic in our case is affected by the continuous horizontal surfaces, more natural and less technogenic urban landscape and good visual quality of the city [3]. We evaluated the planning proposal by all these 16 criteria in five interrelated groups by assigning the corresponding grades for the negative, the neutral or the positive impacts (Tab. 3).

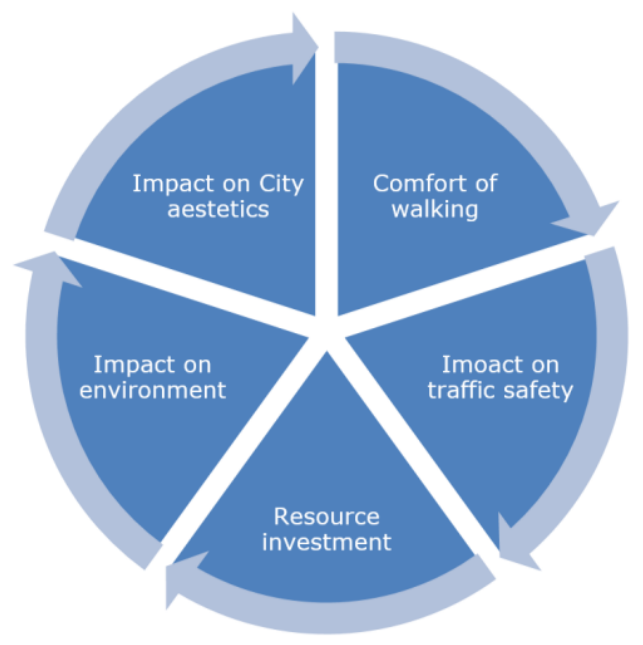

Fig. 8. The complementary set of criteria groups for complex impact assessment. Self-elaboration...

Multicriteria Impact assessment of the proposed measures. Self-elaboration.

\begin{tabular}{|c|c|c|c|c|}
\hline \multirow[t]{2}{*}{ No. } & \multirow{2}{*}{ Criteria group } & \multirow{2}{*}{ Indicators } & \multicolumn{2}{|c|}{$\begin{array}{l}\text { Impact: negative }-1 \text {, } \\
\text { neutral } 0, \text { positive } 1\end{array}$} \\
\hline & & & $\begin{array}{c}\text { Before - status } \\
\text { quo }\end{array}$ & After \\
\hline 1 & $\begin{array}{l}\text { Comfort of pedestrian } \\
\text { walking }\end{array}$ & $\begin{array}{l}\text { Increasing: } \\
\text { 1. smooth mobility } \\
\text { 2. shorter route and time } \\
\text { 3. good visibility } \\
\text { 4. less obstacles for movement }\end{array}$ & $\begin{array}{l}0 \\
0 \\
0 \\
0\end{array}$ & $\begin{array}{l}1 \\
1 \\
1 \\
1\end{array}$ \\
\hline 2 & Overall traffic safety & $\begin{array}{l}\text { Reducing the probability of accidents between: } \\
\text { 5. vehicles and pedestrians } \\
\text { 6. vehicles and cyclists } \\
\text { 7. pedestrians and cyclists }\end{array}$ & $\begin{array}{l}0 \\
0 \\
0\end{array}$ & $\begin{array}{l}1 \\
1 \\
1\end{array}$ \\
\hline 3 & $\begin{array}{l}\text { Resource investment - } \\
\text { impact on economy }\end{array}$ & $\begin{array}{l}\text { Optimising investment of resources for: } \\
\text { 8. construction } \\
\text { 9. refurbishment } \\
\text { 10. maintenance }\end{array}$ & $\begin{array}{l}0 \\
0 \\
0\end{array}$ & $\begin{array}{l}0 \\
1 \\
1\end{array}$ \\
\hline 4 & $\begin{array}{l}\text { Mitigating pollution and } \\
\text { impact on the } \\
\text { environment }\end{array}$ & $\begin{array}{l}\text { Reducing: } \\
\text { 11. noise pollution } \\
\text { 12. air pollution } \\
\text { 13. visual pollution }\end{array}$ & $\begin{array}{l}0 \\
0 \\
0\end{array}$ & $\begin{array}{l}0 \\
0 \\
1\end{array}$ \\
\hline 5 & $\begin{array}{l}\text { Contributing to city } \\
\text { aesthetic }\end{array}$ & $\begin{array}{l}\text { Aesthetics of urban open space } \\
\text { 14. Connected horizontal surfaces } \\
\text { 15. Less technogenic urban landscape } \\
\text { 16. Visual expression }\end{array}$ & $\begin{array}{l}0 \\
0 \\
0\end{array}$ & $\begin{array}{l}1 \\
1 \\
1\end{array}$ \\
\hline & Overall impact result: & & +-0 & +13 \\
\hline
\end{tabular}

\section{Results and discussion}

Analysis of the planning proposal indicate definite reduction of elements that are increasing danger and discomfort of pedestrian mobility in Joniškis town open spaces: if the city implements the plan the number of crossing can be decreased by $25,7 \%$ and the number of drive-ins - by $22 \%$, the overall number of risk-posing elements may be reduced by $26,3 \%$ (Tab. 2). We could say that safety, comfort and satisfaction of pedestrians in the central part of Joniškis town could increase by the same amount if the city implement the proposals. In addition to that, all remaining drive-ins should be re-designed to ramp the driving way over the elevated pedestrian walkways, and that will delete the risk element and further increase the quality of walking in Joniškis.

Results of the qualitative impact-assessment show that in 13 of 16 indicators the proposed urban refurbishment would have positive impact and only in three indicators (construction resource, noise and air pollution) - neutral impact, no negative impact was observed (Tab. 3). The proposed measures will 
definitely increase the comfort of pedestrian walking (positive in four of four indicators) and will positively contribute to the city aesthetics (positive in three of three indicators). Traffic safety for all moving parties would increase in the same way (positive three of three indicators). The economic aspect of resource investment (two of three indicators) and impact on the environment (one of three indicators) show moderate positive impact.

The overall evaluation of the proposed measures shows definite positive impact on walking in urban open spaces as the number of risk-posing infrastructure elements reduces. Looking from the multicriteria perspective, the biggest positive effect is expected in the spheres of pedestrian mobility comfort, traffic safety and city aesthetics. These three aspects are the most important drivers in making urban landscapes and open areas more attractive for the local people and for the visitors. Resource investment and environmental impact are relatively also important but these aspects should be analysed in the wider perspective of economic development and the other environmental measures that the city or the region implements.

\section{Conclusions}

The paper has demonstrated the great positive impact that one technical design detail - ramped drive-in - can have on the attractiveness of the city and quality of life for the citizens. Mobility is recently becoming a critical element in urban development and landscape, and therefore sustainability-based urban mobility solutions should get priority in planning and refurbishing urban open spaces while updating the city master plan, by planning new and upgrading the existing urban districts and landscapes, by designing new buildings and the open areas around or nearby them.

The conceptual measure of SUMP is prioritising pedestrian mobility and cycling against cars transport in the city, and municipal authorities should constantly implement this principle in different available ways. City centres should give priority for pedestrian and other non-motor mobility users as these areas are the most sensitive for the citizen's safety, comfort and pleasure. Empowering this aspect leads the city to the way of sustainable urban development that allows for ensuring higher life quality even with limited material and human resource.

Looking in the wider context, the proposed ramped drive-ins and levelled pedestrian walkways help humanising the city environment and making cities and their landscapes friendlier for the weaker citizens - families with children, people with disabilities and the ageing people whose share is recently growing and will soon make the dominating part of urban residents. These measures help making the cities more attractive for local citizens and visitors and contribute to the growth of social - economic attractiveness of the motivated urban regions.

\section{References}

1. Blecic, I. Canu, D. Cecchini, et al. Walkability and Street Intersections in Rural-Urban Fringes: A Decision Aiding Evaluation Procedure. Sustainability, 2017, Vol.9, p. 883. DOI:10.3390/su9060883 www.mdpi.com/journal/sustainability

2. Clifton, KJ; Smith, ADL; Rodriguez, D. The development and testing of an audit for the pedestrian environment. Landscape and Urban Planning, 2007, Vol. 80(1-2), p. 95-110. DOI: 10.1016/j.landurbplan.2006.06.008.

3. Cullen, G. The Concise Townscape. Oxford: Butterworth Architecture, 1971.

4. ELTIS The Urban Mobility Observatory. European Local Transport Information System. 2018. [online 3.08.2018]. http://www.eltis.org/mobility-plans/sump-concept

5. Gatvès ir vietinès reikšmès keliai. 2011. Statybos techninis reglamentas STR 2.06.04:2011. Lietuvos Respublikos Aplinkos ministerija. Vilnius.

6. Gehl, J. Cities for People. Washington; Covelo; London: Island Press, 2010. ISBN 13-978-1-59726-573-7.

7. Harvey, C.; Aultman-Hall, L. Urban Streetscape Design and Crash Severity. Transportation Research Record, 2015, Issue 2500, p. 1-8. DOI: 10.3141/2500-01

8. Lietuvos pastatu tvarumo vertinimo sistema LPTVS. Lietuvos žaliujų pastatų taryba. Vilnius, 2014. www.lzpt.lt

9. Nadaska, Z. Pilař, P. Conceptual Solution for the Revitalization of Public Spaces in Slovak Towns: case study Stupava. In: Architektura in Perspektive. Perinkova, M; Nedved, M. (eds.). Ostrava: Vysoká škola báňská; Technická univerzita Ostrava, 2017, p. 177-180. ISBN 978-80-248-4058-1.

10. Naharudin, N., Ahamad, M. S. S., Sadullah, A. F. M. Pedestrian-Attractiveness Score for the First/Last Mile Transit Route using Spatial Data Collected with a Mobile Positioning Application. European Navigation Conference (ENC), 2017, New York: IEEE, p. 75-83. ISBN 978-1-5090-5922-5.

11. Nordh, H., Vistad, O. I., Skar, M., et al. Walking as Urban Outdoor Recreation: Public health for everyone. Journal of Outdoor Recreation and Tourism-Research Planning and Management, 2017, Vol. 20, p. 60-66. DOI: 10.1016/j.jort.2017.09.005.

12. Schwebel, D. C. Children Crossing Streets: The Cognitive Task of Pedestrians Across Nations. Annals of Global Health, 2017, Vol. 83(2), p. 328-332. DOI: 10.1016/j.aogh.2017.04.004.

13. Statybos techniniu reikalavimu reglamentas STR 2.03.01:2001. Statiniai ir teritorijos. reikalavimai žmonių su negalia reikmėms. Vilnius: Lietuvos Respublikos Aplinkos ministerija, 2001 
14. Stauskis, G. Monitoring User-Based Accessibility Assessment in Urban Environments and in Public Buildings. TeMA: Journal of Land Use, Mobility and Environment, 2018, Vol. 11(1), p. 89-106. DOI: http://dx.doi.org/10.6092/1970-9870/5426.

INFORMATION ABOUT THE AUTHOR:

Gintaras Stauskis - Doctor of the Humanities in Architecture and a professor at Vilnius Gediminas Technical University (Lithuania). He is lecturing and researching at the Department of Urban Design. He is involved in the European Union research and academic programmes on landscape education, green building and sustainable urbanism. His current research fields include landscape architecture and planning, 'green' urban architecture and mobility, accessibility of environment, recreation and urban health. His research results are presented in numerous national and international publications and conferences. Currently he is leading the Erasmus+ project "Trans-National Education of Landscape Architects". He is a board member at the Lithuanian Green Building Council. More publications at: https://vgtu.academia.edu/GintarasStauskis

Kopsavilkums. Pēdējo divdesmit gadu laikā daudzas Austrumeiropas pilsētas ir kritiski pārpildītas ar automašīnām. Rezultātā, brīvā pilsētas telpa ir kḷuvusi fragmentāra, bet pārvietošanās pilsētā - nedroša. Pētījumā aprakstītas problēmas, kas saistītas ar komfortablu piekḷvi urbānajai videi, izmantojot multidimensionālu pieeju, iekḷaujot estētikas, infrastruktūras un sociālo rīku pielietojumu. Rakstā piedāvāts risinājums Jonišḳu pilsētai (Lietuva), izvērtējot esošo mobilitātes situāciju, izstrādājot uz gājējiem akcentētu rīcības plānu un paredzot ietekmi no pielietotajām metodēm. Multidimensionālās pieejas rezultāti rāda, ka izvirzot gājējus kā prioritāti, var panākt vairākus vides un sociālekonomiskus ieguvumus. Urbānā vide kḷūst drošāka, pievilcīgāka un patīkamāka. Piedāvātais risinājums kalpo kā pētījumu, projektēšanas un izglītošanas vadlīnija ainavu arhitektiem privātajos, publiskajos un nevalstiskajos sektoros. 